\title{
The analysis of the implementation of the program of development of community empowerment around the coal mining sites
}

\author{
Marikha Ulfah Utami ${ }^{1, *}$ and Lana Saria ${ }^{2}$ \\ ${ }^{1}$ Magister Programme, School of Environmental Science, Indonesia University, Jakarta, Indonesia \\ ${ }^{2}$ Directorate General of Minerals and Coal, Jakarta, Indonesia
}

\begin{abstract}
Along with the significant increase of world coal price reaching US\$ $100.69 /$ ton, it can be affects the increase of coal production in Indonesia. On the other hand, coal mining activities cause a number of social and environmental conflicts.. This study examines the implementation of community-based environmental development and empowerment programs and synergies between the Central Government, Regional Governments, Entrepreneurs, and Communities around the mine and and also Community Development costs. The results of interviews and analysis of primary data, the implementation of Community Development carried out by the Company is guided by the Mineral and Coal Law and its implementing regulations such as Government Regulation Number 23 of 2010 concerning the Implementation of Mineral and Coal Mining Business Activities. The results regression statistic showed relationship between variable $\left(\mathrm{R}^{2}=67 \%\right)$, and also equation formula Community Development Costs $=979.296 .927,41+0$ (Operational Costs) $+858,95$ (Coal Productions). Coal Production influences the Community Development Cost variable and the effect is positive. Because the regression coefficient on coal production is positive, which means that if the coal production increases, the Community Development costs will increase.The implementation model of community empowerment programs includes increasing infrastructure and infrastructure, Increased real income, and increased economic independence.
\end{abstract}

\section{Introduction}

Coal is one of the energy resources of electricity generation which in the past few years has been widely used in the world. In Indonesia, coal mining has played an important role in the Indonesian economy. Beginning in 2014 coal prices began to experience a drastic decline and were followed by declining coal production. But at the end of 2016 world coal production began to improve due to a significant increase in world coal prices from US $\$$ 86.23 / ton to US \$ 100.69 / ton according to February Coal Prices (HBA) in February 2018

* Corresponding author: ikha_miner05@yahoo.co.id 
based on Minister of Energy and Mineral Resources Decree Number $407 \mathrm{~K}$ / 32 / MEM / 2018 [1].

Along with the increase in world coal prices, it affected the increase in the amount of coal production in Indonesia. To accommodate this, the government has a mining strategic plan. Based on the strategic plan and the determination of the performance of the Directorate General of Mineral and Coal in 2018, the government has set a plan for coal production of 487 million tons and 365.25 million tons of which are exported and the remaining 25\% (after the DMO quota stipulation based on the Minister of Energy and Mineral Resources Decree) is used domestically for electricity generation and other industries. With the strategic plan, the coal sector can contribute to the country in the form of foreign exchange and various state funding sources such as royalties, taxes, and indirectly contribute to regional economic growth such as employment expansion and physical development. On the other hand, coal mining activities cause a number of sociocultural, environmental and economic inequalities [2], such as economic jealousy conflicts due to lack of good communication and inequality between companies, communities and government.

Therefore, to avoid conflict, companies need to empower the community in accordance with their role in order to create a balanced and proportional relationship [3]. To overcome this problem, the government as a mediator between the community and the company has issued a written regulation regarding the concept of corporate social responsibility. In the field of mineral and coal mining Corporate Social Responsibility (CSR) is regulated in Article 8 of Law Number 4 of 2009 in which the form of CSR, in this case, is a program of development and empowerment of local communities (Community Development or often abbreviated as comdev). Further discussion regarding comdev is regulated in more detail in the Regulation of the Minister of Energy and Mineral Resources No. 41 of 2016 concerning Development and Empowerment of Community Mineral and Coal Mining Business Activities. In the regulation, the company is obliged to compensate in the form of community empowerment development programs (Community Development) as the following aspects: education, health, real income level, economic, social and cultural independence, community participation in managing the environment, the establishment of institutions, infrastructure development.

This research aims to implement development programs and empowerment of communities around the mine by the company, as well as what models of community development and empowerment can increase community independence and can be sustainable and relate to the average amount of budget costs issued by the company or what percentage the average amount of the budget set aside from operational costs.

\section{Methods}

This research discusses about the implementation of community empowerment programs carried out by coal companies in communities around the mine (location) from the social, economic and environmental aspects, as well as the percentage of comdev budget set aside from operational costs. This study uses a quantitative approach. The method used is the mixed method. Quantitative methods are used to collect data on the implementation of comdev from both secondary data and data and information obtained from respondents to be analyzed, while the qualitative method is done by conducting semi-structured interviews 
meaning that it is done freely and in-depth (in-depth interview). The data in this study are in the form of an annual report of a coal company (2012-2016) that will be processed with a data analysis test using regression.

Regression Statistic showed an equation between the cost of community development, operational costs and coal production.

Community development cost $=979.296 .927,41+0($ Operational Costs $)+858,95$ (Coal

Productions)

\section{Result and discussion}

\subsection{Planning for the mining community empowerment development program around mining site}

Mining activities are generally located in remote areas that lack infrastructure with high risks, are capital intensive but are slow to produce, and have an environmental and social impact [4], but as time goes by and mining technology is now close to rural areas, urban even the community's fields. With the existence of mining activities, it is expected that this mining business will trigger the development of the region because mining is temporary, its reserves are limited and cannot be renewable, therefore, in this case, the concept of the company is not based on the single bottom line in the form of economic aspects which are shown in terms of financial acceptance, but must pay attention to social and environmental aspects [5]. The mining company is tasked with developing its business so as to produce an advantage for the country, region, and society in the form of employment and social programs. But not only mining companies have responsibility for this. National and local governments and the community also play an important role in advancing the region. Thus, all will be able to improve their welfare by utilizing the results of development carried out by the government and mining companies together with the community, which is one of the ways the company is doing community development and community development programs around the mining sites.

Basically, the concept of community development (comdev) is a process whereby people living in certain locations develop initiatives to carry out an action (with or without intervention) to change their economic, social, cultural and environmental situation according to the needs and problems of the community [6]. In essence, comdev is a process of socio-cultural adaptation carried out by industry, central and regional governments towards the activities of local communities [7]. Meanwhile, community development is a community development activity carried out systematically, planning, and directed to increase public access to improve social, economic, and quality of life conditions that are better compared to previous development activities [8]. Every community development planning and implementation company must carry out social mapping and deliberations carried out jointly between the company, the community, and the Government (Central and Regional) so that the planned program can run well and not overlap with the government program [9].

From the observations in the field, currently, the implementation of community development carried out by the Company is guided by the Mineral and Coal Law and its implementing regulations such as Government Regulation Number 23 of 2010 concerning Implementation of Mineral and Coal Mining Business Activities as well as several other technical regulations. several stages of the implementation are : 
a. The company must first conduct social mapping (social mapping) of the community around the mining location.

b. Based on the results of social mapping, the company prepares a master plan for its preparation:

- Involves the leadership of the local regional government, community, and other community development stakeholders

- Guided by the community development blueprint set by the Governor (if any).

- Prepared together with the feasibility study document or become part of the feasibility study document then consulted with the Director General of Mineral and Coal on behalf of the Minister of Energy and Mineral Resources or the Governor in accordance with the authority.

c. The community development master plan contains the implementation from the beginning of production activities to post-mining, the master plan can be changed or evaluated once every 5 years. This is can use for preparing the program and annual community developement costs around the Mining Business Permit Area (WIUP) and the Special Mining Business License Area (WIUPK). It can be affected by mining activities or in other words, communities that are close to mining operations by not seeing the administrative boundaries of sub-districts / districts.

d. An annual community development program that refers to the community development master plan is consulted with the Government or provincial government and the local community whose purpose is to synchronize the community development program with development programs planned and financed through the regional budget (APBD), this is to prevent overlapping of program implementation and costs. , which leads to inefficiencies in activities and budgets, and local communities can submit proposals for community development activities to local regents/mayors to be forwarded to the Company.

e. The company is obliged to finance the community development program from the allocation of community development program costs to the Company's budget and costs every year. Where the cost allocation comes from operational costs managed by the Company.

\subsection{Relationship between cost of community empowerment program and mining company operational costs and coal production}

The influence of the relationship between Program community development Costs and Operational Costs and Coal Production based on the 18 annual results report of companies from 2012 - 2016, related to several variables that meet them;

1. $\mathrm{Y}$ is program community development Costs (IDR)

2. $\mathrm{X} 1$ is Operational Costs (IDR)

3. X2 is Coal Productions (tons)

Based on descriptive Statistic showed that between 2012 - 2016 the average Program community development costs incurred amounted to IDR $14,512,533,440$, with an average production cost of IDR 7,646,178,641,406, and the average coal production of $13,398,970$ tons.

Regression Statistic Analysis reports the strength of the relationship between the model (independent variable) and the dependent variable. Multiple R (compound compound) is a measure to measure the level (closeness) of a linear relationship between the dependent variables and all independent variables together. The $\mathrm{R}$ number of 0.82 indicates that there 
is a relationship between the cost of community development program and Operational Costs and coal production. R Square (R2), often referred to as the coefficient of determination, is measuring goodness of fit from the regression equation; that is giving the proportion or percentage of the total variation in the dependent variable explained by the independent variable. R Square number of 0.67 or $67.1 \%$ shows that the relationship between Program community development costs and operational costs and coal production is not very strong because there are still many factors $32.9 \%$ influenced by external factors.

Anova calculation showed the Significance F 0.00, indicating that simultaneously (together) Operational Costs and Coal Production have a significant effect on Program community development Costs. (95\% confidence level).

From the above equation, it shows that the regression coefficient of operational costs is positive, meaning that when operational costs are still in the normal category, the company's PPM costs will increase. While the relationship between coal production and PPM costs is positive, or every increase in one-unit coal production, the output will increase by 858.95 for each 1 ton increase in coal production. Based on the results of hypothesis testing, both the $\mathrm{T}$ test and the $\mathrm{F}$ test, it is known that the variable number of the Coal Production influences the Program community development Cost variable and the effect is positive. Because the regression coefficient on coal production is positive, which means that if the coal production increases, the Program community development costs will increase.

\subsection{Model of implementation of mining community development and empowerment around mining sites}

From the results of field observations, several models of community development activities and post-mining land use for community development activities are :

a. Activities of PT Kaltim Prima Coal, which utilizes Hole Ex-Mine (Void) for sustainable development in partnership with the Regional Water Company in the management of clean water for the surrounding communities in the region Sanggata, East Kalimantan with affordable and equitable (can be enjoyed by the public many). This contributes in the form of income for the area and cleans water resources for the communities around the mine. Source water comes from Telaga Batu Arang.

The source of clean water that comes from Lake Batu Arang is a mining plateau that previously left the pit gradually filled with water. Before handing over to the Regional Water Company, PT KPC monitored the proper water quality. environmental quality standards that will be consumed by the community, and build supporting infrastructure for distribution to PDAMs and the community. Then KPC developed aquaculture in Batu Arang Lake. Fish, catfish, carp, and tilapia fish that are similar in ponds at the pond site are named nursery cages (figure 1).

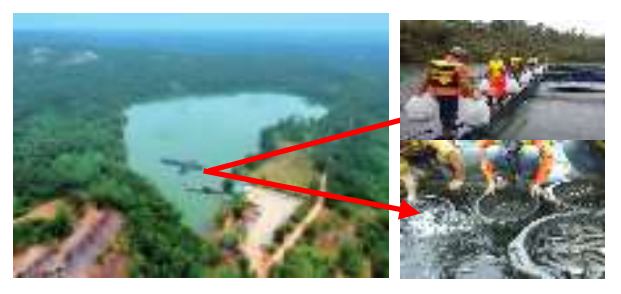

Fig. 1. (a) Condition Lake of Batu Arang, Separating Cage, Lake of Batu Arang (Sanggata Regency, East Kalimantan) (b) Fishing activity at Lake Baru Arang 
b. Activities of PT Kideco Jaya Agung (KJA), which made the concept of Integrated Farming System (IFS), where the IFS is a system that connects agricultural activities, livestock, fisheries, forestry and other things related to agriculture in one field. The program aims to increase land productivity, environmental conservation and increase the economy of the community. This IFS program has been implemented since 2011 until now. The location is in Samurangau Village, Kec. Batu Sepong, Kab. Paser. The area reaches 6.5 hectares integrated with other assisted locations (Figure 2).

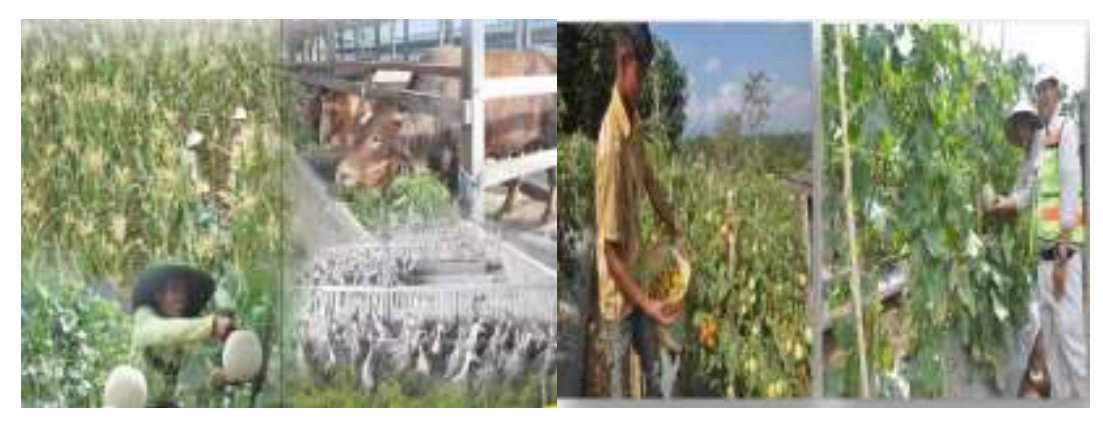

Fig. 2. Integrated farming system (Samurangau Village, Paser Regency, East Kalimantan).

In addition, KJA also helps increase the real income of the community through the provision of oil palm seeds and provide assistance and guidance to improve the economy and institutions. The KJA assisted community once formed a cooperative but the establishment of this cooperative did not only take place in a period of 1 year, from the results of interviews that researchers could conclude that this cooperative could not run because of lack of trust between managers and members of cooperatives. Therefore, it is very important that there is trust in an organization, where according to Adimiharja (2011) in the book Socially Responsible Corporation "Map of Problems, Social Responsibility and Community Development in the Mining and Oil and Gas Industry in Indonesia, social capital is part of social organizations, such as trust, norms and networks that can improve the efficiency of society in carrying out an action. Social capital has the role of providing convenience in accessing information, becoming a media for sharing power in the community, developing solidarity, for mobilizing community resources, for mutual achievement, and for forming organizational behavior.

From the previous discussion, researchers can create a model for implementing the community development program that can increase economic independence and develop sustainability (Figure 3).

In the case of implementing community development programs, researchers create models to increase community independence so that the development of an area continues after the absence of mining activities in the area by:

a. Increased infrastructure and infrastructure to support activities in education, health, social and culture such as traditional houses, houses of worship and others to facilitate and provide comfort for the community.

b. Increased real community income by providing assistance such as the provision of oil palm seeds, fish seeds, assistance in other fields such as trade, agriculture, entrepreneurship and others that can increase the income of communities around the mine 
c. Increased economic independence, where the aim is to provide assistance and a community access facility in terms of forming, developing small and medium enterprises.

d. The establishment of institutions or regionally owned business entities that will be useful for community stagnation and economic wheel turnover after the absence of mining activities.

$\boldsymbol{e}$. Along with programs to increase real income, economic independence and institutional formation, improve the quality of human resources through mentoring, education, training, scholarships, or training and community independence and

f. Improve the quality of healthy life by participating in the sustainable environmental management of the community around mining sites

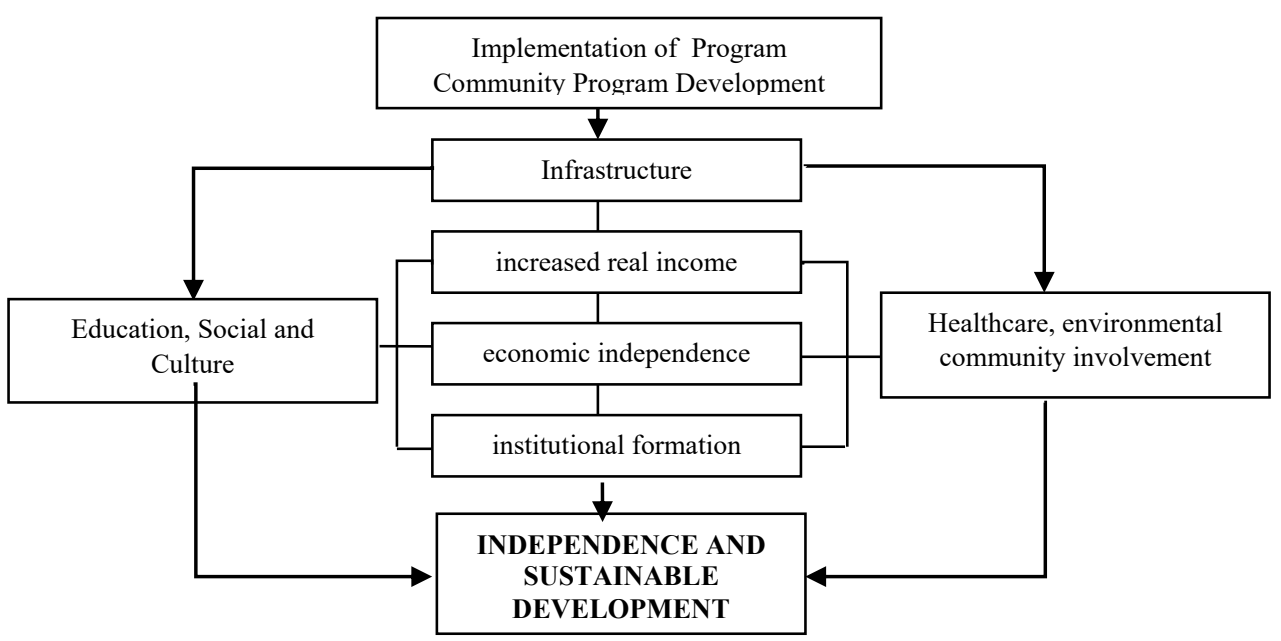

Fig. 3. The model of implementation community development.

\section{Conclusion}

1. Results of interviews and analysis of primary data, the implementation of community development carried out by the Company is guided by the Mineral and Coal Law and its implementing regulations such as Government Regulation Number 23 of 2010 concerning Implementation of Mineral and Coal Mining Business Activities.

2. Based on Regression, there ara relationship between community devlopment Costs, Operational Costs, Coal Productions $\left(\mathrm{R}^{2}=67.1 \%\right)$. Coal Production influences the community development Cost variable and the effect is positive. Because the regression coefficient on coal production is positive, which means that if the coal production increases, the community development costs will increase.

3. The implementation model of community empowerment programs includes increasing infrastructure and infrastructure, Increasing real income, Increasing economic independence, forming institutions, training / training / scholarships or community independence, and sustainable environmental management of the community around mining sites 


\section{References}

1. Alfitri, Community Development Theory and Application, (Publisher of learning library, Yogyakarta, 2011)

2. Bato, E. Marthen, Y. Amar, and I. Pabo. Ann. Report 5 (2016)

3. Budimanta, A. Ann. Report, Indonesia Center for Sustainable Development (2016)

4. Elkington J, Cannibals With Forks: The Triple Bottom Line in 21st Century Business (BC: New Society Publishers, Gabriola Island, 1998)

5. Fajar, Mukti, Corporate Social Responsibility, Study of the Implementation of CSR in National Private Multinational Enterprises and SOEs in Indonesia (Publisher of learning library, Jakarta, 2010)

6. S. Gumanti, R. Juniah, and Taqwa, Empirical Journal, 1 (2016)

7. http://pmb.lipi.go.id/

8. D. Prayogo, Ann. Report, Indonesia Center for Sustainable Development (2011)

9. B. Rudito, The improvement of community economy as impact of corporate social responsibility program: A case study in Pengalengan, Bandung, West Java, Indonesia. (ICAS, Malaysia, 2014)

10. Law of the Republic of Indonesia Number 4 of 2009 concerning Mineral and Coal Mining Government Regulation Number 23 of 2010 concerning Implementation of Mineral and Coal Mining Business Activities 